\title{
Potential pesticide of three essential oils against Spodoptera frugiperda (J.E. Smith) (Lepidoptera: Noctuidae)
}

\author{
Kássio E.S. Sombra ${ }^{1 *}$, Caio V.S. de Aguiar $^{2}$, Sabrina J. de Oliveira ${ }^{3}$, Marianne G. Barbosa ${ }^{4}$, \\ Guilherme J. Zocolo ${ }^{5}$, and Patrik L. Pastori ${ }^{6}$
}

\begin{abstract}
${ }^{1}$ Universidade Federal Rural do Semi-Árido, Pós Graduação em Fitotecnia, 59.625-900, Mossoró, RN, Brasil.
"Corresponding author (kassiosombra@gmail.com).

${ }^{2}$ Instituto Nacional de Pesquisas da Amazônia, Pós-Graduação em Agricultura no Trópico Úmido, 69060-001, Manaus, AM, Brasil.

${ }^{3}$ Universidade Estadual Paulista "Júlio de Mesquita Filho", Pós-Graduação em Agronomia, 14884-900, Jaboticabal, SP, Brasil.

${ }^{4}$ IN Soluções Biológicas Ltda., 60440-593, Fortaleza, CE, Brasil.

${ }^{5}$ Empresa Brasileira de Pesquisa Agropecuária, Embrapa Agroindústria Tropical, 60511-11, Fortaleza, CE, Brasil.

${ }^{6}$ Universidade Federal do Ceará, Departamento de Fitotecnia, CEP 60356-001 Fortaleza, CE, Brasil.
\end{abstract}

Received: 28 May 2020; Accepted: 25 July 2020; doi:10.4067/S0718-58392020000400617

\section{ABSTRACT}

The alternative use of plant essential oils as pesticide, repellent and/or antifeedant has been emphasized as an important tool in integrated pest management (IPM), promoted by the growing interest in methods that fulfil requirements of efficiency, safety, selectivity, technically feasible and environmentally safe. The objective of this work was to determine the pesticide potential of essential oils of rosemary pepper (Lippia origanoides Kunth; Verbenaceae), citronella (Cymbopogon winterianus Jowitt; Poaceae) and lemongrass (Cymbopogon citratus [DC.] Stapf; Poaceae) to control fall armyworm (Spodoptera frugiperda [J.E. Smith]; Lepidoptera: Noctuidae). Ovicidal, larvicidal and pupicidal activity was evaluated with five dosages $(0.1 \%, 0.5 \%, 1.0 \%, 2.5 \%$ and $5.0 \% \mathrm{v} / \mathrm{v})$ and a negative control (neutral detergent at $5.0 \% \mathrm{v} / \mathrm{v}$ ). Unhatched eggs, mortality of caterpillars and non-emerged adults were recorded using ovicidal and pupicidal percentage, and median lethal doses $\left(\mathrm{LD}_{50}\right)$ to caterpillars. The essential oils showed insecticidal activity on the egg, caterpillar $3^{\text {rd }}$ instars and pupae stages, highlighting the rapid action and high mortality rates caused by the L. origanoides essential oil, which registered, at lowest dosage, average $97.8 \%$ ovicidal activity and $81.3 \%$ pupicidal activity; in addition to $\mathrm{LD}_{50}$ on $3^{\text {rd }}$ instar caterpillars, $0.001 \%$ by exposure and $0.033 \%$ by topical application. Essential oils of $C$. citratus and $C$. winterianus required longer periods to act and caused significant mortality on the three stages, registering $\mathrm{LD}_{50}$ $0.008 \%$ and $0.159 \%$ for exposure, and $1.151 \%$ and $1.348 \%$ for topical application, respectively. Citronella oil caused behavioral changes in caterpillars, which reflected flight and aggressiveness. Therefore, these three essential oils can be an alternative for management of fall armyworm, with the potential to hinder and reduce its biotic potential.

Key words: Agroecology, alternative control, botanical pesticides, entomology, fall armyworm, integrated pest management, Zea mays.

\section{INTRODUCTION}

The fall armyworm, Spodoptera frugiperda (J.E. Smith) (Lepidoptera: Noctuidae), is a lepidopteran native to the tropical and subtropical regions of the American continent, with a polyphagous habit, it established itself as an important lepidopteran-pest in corn crop (Zea mays L.; Poaceae) (Goergen et al., 2016), standing out for its high biotic potential and widespread occurrence in the Americas, Asia and Africa (Early et al., 2018). The caterpillars can attack and feed on maize plants, from seedling emergence to cob formation, reducing photosynthetic activity and causing significant losses in crop yield (Goergen et al., 2016). 
Control of the fall armyworm has usually been performed using synthetic pesticides, such as organophosphates and neonicotinoids, and genetically modified (transgenic) plants (Botha et al., 2019), which are capable of releasing Bacillus thuringiensis (Bt) toxins (Bateman et al., 2018). However, the inadequate use of these technologies has led to the emergence of resistant populations, as well as the reduction of natural enemies' populations and beneficial organisms. Therefore, the search for methods that meet the requirements of efficacy, safety and selectivity become increasingly important, calling the attention to alternative control with aromatic plant essential oils (Alves et al., 2018; Ayil-Gutiérrez et al., 2018; González-Castillo et al., 2018).

Essential oils are composed of complex secondary metabolites mixtures, which evolutionarily became the mechanisms of plant defense against insects and phytophagous mites, that extracted and exogenously applied can confer insecticidal, repellent or antifeedant activities (Isman, 2015). Plants of the genus Lippia, for example, have become important sources of insecticidal compounds, mainly by the presence of thymol (2-isopropyl-5-methylphenol) and carvacrol (2-methyl-5(1-methylethyl)) (Regnault-Roger et al., 2012; Dos Santos et al., 2016). These aromatic monoterpenes are responsible for conferring to essential oils of Thymus vulgaris L. (Lamiaceae), wild marjoram Origanum vulgare L. (Lamiaceae) and rosemary pepper species such as Lippia sidoides Cham. and L. origanoides Kunth (Verbenaceae), the potential to cause death, reduce or inhibit feeding and oviposition (antifeedance) (El-Wakeil, 2013), against different arthropod pests such as maize weevil Sitophilus zeamais Mots. (Coleoptera: Curculionidae) (Oliveira et al., 2018) and silverleaf whitefly Bemisia tabaci (Genn.) (Hemiptera: Aleyrodidae) (Vite-Vallejo et al., 2018). As for the essential oil of lemongrass, Cymbopogon citratus (DC.) Stapf (Poaceae), composed of citral (3,7-dimethyl-2,6-octadienal) and citronellal (3,7-dimethyloct-6-en1-al), it may confer repellent action against red flour beetle Tribolium castaneum (Herbst.) (Coleoptera: Tenebrionidae) (Olivero-Verbel et al., 2010). Meanwhile, Java citronella oil, Cymbopogon winterianus Jowitt (Poaceae), consisting of geraniol [(2E)-3,7-dimethylocta-2,6-diene-1-ol)], citronellol (3,7-dimethyloct-6-en-1-ol) and citronellal, may confer repellency to adults of dengue transmitter mosquito Aedes aegypti L. (Diptera: Culicidae) (Suwansirisilp et al., 2013), besides insecticidal action on thrips Frankliniella schultzei Trybom (Thysanoptera: Thripidae) and green aphid Myzus persicae Sulzer (Hemiptera: Aphididae) (Pinheiro et al., 2013).

In view of this, studies on the phytosanitary use of essential oils from different aromatic plants have increased in recent decades (Regnault-Roger et al., 2012; Alves et al., 2018; Mendoza-García et al., 2019), motivated by the low number of commercial products that have been produced, mainly with extracts and oil of Indian neem Azadirachta indica A. Juss. (Meliaceae). Neem-based products can have multiple modes of action, capable of promoting toxicity due to anti nutrient effects and growth regulation, acting against different arthropod pests of economic importance (Benelli et al., 2017). However, the intensification of their long-term use may cause similar risks when observed with the use of synthetic insecticides, making it necessary to prospect for essential oils with insecticidal, repellent or phage inhibitor activity, which may increase the diversity of products on the market, generating innovation and expanding tools for integrated pest management programs (Regnault-Roger et al., 2012; Alves et al., 2018).

This work aimed to evaluate the insecticidal potential of essential oils of rosemary pepper (L. origanoides), citronella (C. winterianus) and lemongrass (C. citratus) against egg stages, larva and pupa of $S$. frugiperda.

\section{MATERIALS AND METHODS}

The work was carried out in a climatized room $\left(25 \pm 3{ }^{\circ} \mathrm{C}, 70 \pm 10 \% \mathrm{RH}\right.$ and 12:12 h photophase) at the Laboratório de Entomologia Aplicada of the Universidade Federal do Ceará, Fortaleza ( $3^{\circ} 44^{\prime} 32.37^{\prime \prime}$ S, 38³4'30.38” W), Ceará State, Brazil.

\section{Insect rearing}

The rearing was established from caterpillars collected in commercial cultivation areas in the Municipalities of Quixeré and Limoeiro do Norte, Ceará State, Brazil, and maintained using artificial diet proposed by Greene et al. (1976). The collections were performed in the morning, observing the presence of damages or feces in the leaf sheath region of corn plants (Zea mays L.) to locate the caterpillars and transfer them to glass tubes $(100 \times 25 \mathrm{~mm})$ containing artificial diet. The tubes were buffered with hydrophobic cotton and transported to laboratory, where they were kept under controlled conditions until pupae were formed which, after being removed from the diet residue, were placed in Petri dishes $(90 \times 15$ $\mathrm{mm}$ ), and they remained there until the emergence of the adults. The adults were transferred to polyvinylchloride (PVC) cylindrical cages $(10 \times 25 \mathrm{~cm})$, containing $10 \%$ of honey solution (feeding), covered with paper towels (oviposition) and 
closed at the ends with 'voil' type tissue. The solution and paper towels were changed every $2 \mathrm{~d}$ by cutting out the egg masses and placing them in Petri dishes $(90 \times 15 \mathrm{~mm})$. After $3 \mathrm{~d}$, the newly hatched caterpillars were transferred, with the aid of a fine-haired brush, to glass tubes $(100 \times 25 \mathrm{~mm})$ containing an artificial diet, using the following generations in bioassays.

\section{Extraction and chemical characterization of essential oils}

The essential oils were extracted in the laboratory using the 'hydrodistillation technique' and provided by Agropaulo Agroindustrial S.A., Jaguaruana, Ceará State, Brazil. The oils were stored refrigerated in amber glass and sent to the Natural Products Chemistry Laboratory in Embrapa Agroindústria Tropical (Fortaleza, Ceará State, Brazil) for analysis of the chemical composition through gas chromatography with mass spectrometer (GC-MS), determining the Kovats retention indices (IK) and the spectra of masses of each constituent on an GC-MS chromatograph (Agilent, Santa Clara, California, USA). The majority compounds were identified by comparison with the literature (Adams, 2007), and listed in Table 1.

\section{Experimental design}

The bioassays were carried out in a completely randomized design, $3 \times 5$ factorial scheme, to evaluate the activity of the essential oils of rosemary pepper (Lippia origanoides Kunth), citronella (Cymbopogon winterianus Jowitt) and lemongrass (C. citratus [DC.] Stapf), at doses of 0.1\%, 0.5\%, 1.0\%, $2.5 \%$ and 5.0\% essential oil per liter of water (v/v),

Table 1. Majority compounds content of essential oils by GC-MS.

\begin{tabular}{|c|c|c|c|c|}
\hline Compounds & $\mathrm{IK}^{\mathrm{a}}$ & $\begin{array}{c}\text { Lippia } \\
\text { origanoides }\end{array}$ & $\begin{array}{l}\text { Cymbopogon } \\
\text { winterianus }\end{array}$ & C. citratus \\
\hline & & & $\%$ & - \\
\hline 3-Carene & 1014 & - & - & 29.01 \\
\hline$(E, E)-2,4$-Decadienal & 1314 & - & - & 25.95 \\
\hline Acetophenone & 1058 & 32.75 & - & - \\
\hline$\alpha$-Cadinene & 1537 & 0.27 & 1.37 & 0.31 \\
\hline$\alpha$-Citral & 1266 & - & 0.44 & 16.22 \\
\hline$\alpha$-Fenchene & 946 & 1.96 & - & - \\
\hline$\alpha$-Himachalene & 1452 & 10.38 & - & 0.33 \\
\hline$\alpha$-Pinene & 940 & 5.08 & 0.23 & - \\
\hline$\alpha$-Terpinene & 1017 & 0.31 & - & - \\
\hline$\beta$-Caryophyllene & 1409 & - & 3.44 & - \\
\hline$\beta$-Cubebene & 1393 & 1.72 & - & - \\
\hline$\beta$-Myrcene & 999 & 3.90 & 1.01 & - \\
\hline$\beta$-Pinene & 979 & 0.39 & 0.16 & - \\
\hline Carvacrol & 1333 & 30.37 & - & - \\
\hline Citronellol acetate & 1363 & - & - & 0.28 \\
\hline D-Limonene & 1040 & - & - & 0.94 \\
\hline Eugenol & 1364 & - & 1.22 & - \\
\hline Isopulegol & 1164 & - & - & 5.75 \\
\hline Geraniol & 1249 & - & 3.44 & - \\
\hline Geranyl acetate & 1396 & - & 1.67 & 0.45 \\
\hline Lavandulyl acetate & 1283 & - & 5.90 & - \\
\hline Longifolene & 1407 & - & - & 0.82 \\
\hline Menthone & 1197 & - & 55.97 & - \\
\hline Methyl thymyl ether & 1244 & 1.95 & - & - \\
\hline$p$-Cymenene & 1091 & 0.62 & - & - \\
\hline$P$-Menth-8-en-2-one, trans- & 1188 & - & - & 1.90 \\
\hline Perillen & 1107 & - & - & 1.71 \\
\hline Rose oxide & 1115 & - & 1.21 & - \\
\hline Terpinolene & 1083 & 7.96 & 0.38 & - \\
\hline trans- $\beta$-Ocimene & 1047 & - & 0.09 & 0.83 \\
\hline Valencene & 1496 & - & 1.12 & - \\
\hline$\gamma$-Terpinene & 1049 & 0.42 & 18.35 & 0.57 \\
\hline (S)-cis-Verbenol & 1280 & - & - & 10.42 \\
\hline Total & & 98.08 & 96.00 & 95.49 \\
\hline
\end{tabular}

${ }^{a}$ Kovats retention index (IK) by GC-MS. 
determined in preliminary dose/mortality tests and previously dissolved with the support of neutral detergent (1:1), on the egg stages, caterpillar and pupae of S. frugiperda. Five replicates per treatment were installed, and using 20 eggs, 10 caterpillar $3^{\text {rd }}$ instars, identified according to the width of the cephalic capsule, or 10 pupae of $S$. frugiperda per replicate. The negative control consisted of distilled water and $5.0 \%(\mathrm{v} / \mathrm{v})$ of neutral detergent used to correct the results obtained with essential oils.

\section{Bioassay of ovicidal activity}

Ovicidal activity was determined using sky blue cardboard cards $(4 \times 2 \mathrm{~cm})$ containing eggs up to $24 \mathrm{~h}$ old, collected at rearing and glued equidistantly using $20 \%$ gum Arabic solution, with the aid of a hair brush thin and stereoscopic microscope. The cards were placed on filter paper and sprayed with $200 \pm 20 \mu \mathrm{L}$ essential oil solutions or control using a hand sprayer. After $30 \mathrm{~min}$, the cards (replicates) were organized in Petri dishes $(90 \times 15 \mathrm{~mm})$, closing them with PVC plastic film.

The deterioration or hatching of S. frugiperda eggs was evaluated daily for $7 \mathrm{~d}$, calculating the percentage of ovicidal activity as described by Sangha et al. (2017):

$$
\operatorname{OAP}(\%)=(E U W-E U T / 100-E U W) \times 100
$$

where OAP is ovicidal activity percentage, EUW is unhatched eggs in the control, and EUT is unhatched eggs in essential oil treatments.

\section{Larvicidal activity bioassay by surface exposure}

Exposure larvicidal activity bioassay was performed using filter paper discs $(85 \mathrm{~mm})$ impregnated with $0.8 \mathrm{~mL}$ essential oil's solutions or controls, placed in Petri dishes $(90 \times 15 \mathrm{~mm}$ ) and allowed to stand $30 \mathrm{~min}$ (Olivero-Verbel et al., 2010; Dos Santos et al., 2016). After drying, the caterpillars were released in the center of the treated surfaces, providing an artificial diet fragment (Greene et al., 1976) to prevent starvation, and closing the plates with plastic film. Accumulated mortalities were evaluated after 6,12,24 and $48 \mathrm{~h}$ exposure to surface treated with essential oil solutions or controls, considering as dead caterpillars those that showed no observable response to mechanical stimulation, performed with a fine hairbrush. After $48 \mathrm{~h}$ exposure, the surviving caterpillars were removed and transferred to glass tubes $(100 \times 25 \mathrm{~mm})$ containing an artificial diet (Greene et al., 1976), being therefore recorded the number of pupae formed and emerged adults. Subsequently, the observed mortality was corrected in relation to the negative control, using the formulas proposed by Abbott (1925), described below:

$$
\% \mathrm{M}=(\mathrm{NCKT} / \mathrm{TNCT}) \times 100
$$

where $\% \mathrm{M}$ is mortality percentage, NCKT is number of caterpillars killed in treatment, and TNCT is total number of caterpillars in treatment.

$$
\mathrm{Mc}(\%)=(\% \mathrm{Mo}-\% \mathrm{Mt} / 100-\% \mathrm{Mt}) \times 100
$$

where Mc is mortality corrected, Mo is observed mortality, and Mt is negative control mortality.

\section{Larvicidal activity bioassay by topical application}

In the second larvicidal activity bioassay, $1 \mu \mathrm{L}$ essential oil solutions or control was applied topically to the mesothorax of S. frugiperda caterpillars, previously placed, with the aid of a fine hair brush, in glass tubes $(100 \times 25 \mathrm{~mm})$ containing artificial diet (Greene et al., 1976; Melo et al., 2018). The tubes were buffered with hydrophobic cotton and arranged in upright shelves. Accumulated mortalities were assessed 6,12,24, and $48 \mathrm{~h}$ after topical application of essential oil solutions or control. The surviving caterpillars remained in the glass tubes $(100 \times 25 \mathrm{~mm})$ and were able to feed on an artificial diet (Greene et al., 1976), recording the number of pupae formed and emerged adults. Observed mortality was also corrected for the control using the formulas proposed by Abbott (1925).

\section{Pupicidal activity bioassay}

Pupicidal activity (Baskar et al., 2009) was determined using pupae of $S$. frugiperda up to $48 \mathrm{~h}$-old, placed on filter paper and sprayed with $200 \pm 20 \mu \mathrm{L}$ essential oil solutions or control using a hand sprayer. After $30 \mathrm{~min}$, the pupae were placed in petri dishes $(90 \times 15 \mathrm{~mm})$ containing filter paper, and the plates were closed with PVC plastic film. 
Pupal mortality and adult emergence were evaluated daily for $15 \mathrm{~d}$ and values were used to calculate the percentage of pupicidal activity (PPA), as adapted from Sangha et al. (2017):

$$
\mathrm{PPA}(\%)=(\mathrm{AEC}-\mathrm{AET} / 100-\mathrm{AEC}) \times 100
$$

where AEC is adults non emerged in controls, and AET is adults non emerged from essential oil treatments.

\section{Statistical analysis}

The average of corrected mortality rate $(\mathrm{CM})$ was subjected to Probit analysis in order to determine dose-mortality curves (Finney, 2009), and by average of curves estimate median lethal doses $\left(\mathrm{LD}_{50}\right)$ for mortality of $50 \%$ of the lepidopteranplague populations. Quantitative data were submitted to ANOVA comparing the average in cases of significant difference by Tukey test at $5 \%$ probability $(\mathrm{p} \leq 0.05)$, with the aid of statistical software Sisvar (Departamento de Estatística, Universidade Federal de Lavras, Lavras, Minas Gerais, Brazil).

\section{RESULTS}

Significant differences were found between the essential oils of rosemary pepper (L. origanoides), citronella (C. winterianus) and lemongrass $(C$. citratus $)$ in the ovicidal $(\mathrm{p}<0.05)$, larvicide (exposure and topical application) and pupicidal $(\mathrm{p}<0.01)$ (Table 2$)$ activity bioassays. However, the dosages of essential oils did not differ in ovicidal activity in each oil, although differing in larvicidal and pupicidal activities $(\mathrm{p}<0.01)$, generally inferring an increase in mortality rates as essential oil dosages increased (Table 2).

The three essential oils demonstrated ovicidal activity percentage (OAP), altering and reducing the hatching of S. frugiperda caterpillars after spraying of the blisters, although they differ only in the $0.1 \%$ dosage, and the solutions of L. origanoides and C. citratus matched $97.8 \%$ ovicidal potential, and differed from the $C$. winterianus oil solution, which recorded only $78.02 \%$ ovicidal potential (Figure 1). The spraying of the solutions on the eggs, in addition to inducing non hatching, caused in some cases their partial or total deterioration, with up to $71 \%$ of eggs deteriorated after the application of $1.0 \%$ C. citratus oil solution, whereas eggs treated with $0.1 \%$ solution only deteriorated $11 \%$.

Rosemary pepper (L. origanoides) essential oil showed greater larvicidal activity in the bioassay due to exposure on treated surface, standing out after its application and causing $60.41 \%$ of larval mortality to $0.1 \%$ after 6 h exposure. However,C. winterianus essential oil solutions required longer exposure periods to act and express their larvicidal potential, as found at the $0.1 \%$ dosage that after $6 \mathrm{~h}$ had induced only $1.25 \%$ mortality, but gradually reached $47.9 \%$ mortality after $48 \mathrm{~h}$ (Figure 2). Nevertheless, despite the lower larvicidal potential, caterpillars exposed to citronella solutions presented obvious behavioral changes such as confusion, escape and greater aggressive behavior, than caterpillars exposed to other essential oil solutions. The solutions with essential oil of $C$. citratus also needed greater exposure period to act, however, the effects were similar to L.origanoides, ranging from paralysis followed by necrosis and tissue stiffening, evolving with the death of caterpillars (Figure 2).

Table 2. ANOVA for ovicidal activity percentage (OAP), larvicidal potential, treated surface exposure and topical application, and pupicidal activity percentage (PPA) of three essential oils on Spodoptera frugiperda.

\begin{tabular}{|c|c|c|c|c|c|}
\hline \multirow[b]{3}{*}{$\begin{array}{l}\text { Source of } \\
\text { variance }\end{array}$} & \multirow[b]{3}{*}{ GL } & \multirow[b]{3}{*}{ OAP } & \multicolumn{2}{|c|}{ Square averages } & \multirow[b]{3}{*}{ PPA } \\
\hline & & & \multicolumn{2}{|c|}{ Larvicidal potential } & \\
\hline & & & $\begin{array}{c}\text { Treated surface } \\
\text { exposure }\end{array}$ & $\begin{array}{c}\text { Topical } \\
\text { application }\end{array}$ & \\
\hline Essential oils & 2 & $366.54 *$ & $9638.20 * *$ & $36433.28 * *$ & $693.56^{* *}$ \\
\hline Doses & 4 & $264.89^{\text {ns }}$ & $1827.40 * *$ & $4808.20 * *$ & $552.84 * *$ \\
\hline Oils $\times$ Doses & 8 & $137.02^{\mathrm{ns}}$ & $114.97^{\mathrm{ns}}$ & $568.73^{\mathrm{ns}}$ & $295.00 * *$ \\
\hline Residues & 135 & 122.21 & 277.12 & 510.44 & 79.19 \\
\hline $\mathrm{CV}, \%$ & & 11.80 & 23.41 & 38.40 & 11.93 \\
\hline
\end{tabular}

*, **Significant at the $5 \%$ and $1 \%$ probability level, respectively; ${ }^{\text {s: }}$ : nonsignificant; GL: degrees of freedom. 
Figure 1. Ovicidal activity percentage (OAP) (A) and Spodoptera frugiperda egg spoilage (B) of sprayed essential oil solutions. Fortaleza, Ceará State, Brazil.
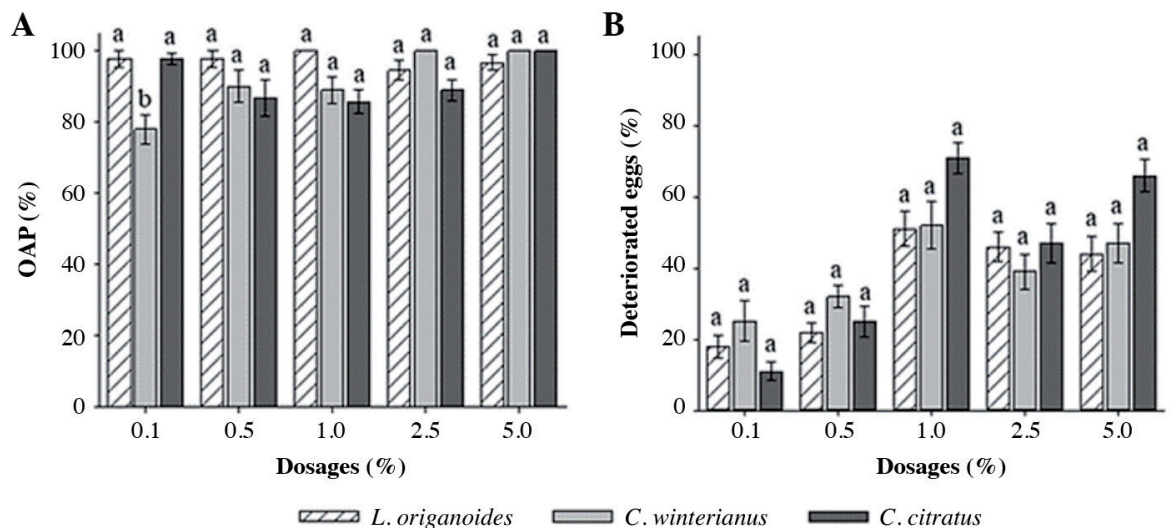

Different letters on bars corresponding to the same dosage indicate significant differences between essential oils according to Tukey test $(\mathrm{P}<0.05)$. Vertical bars correspond to standard error.

Lippia origanoides, Cymbopogon winterianus and Cymbopogon. citratus.

Figure 2. Corrected mortality of caterpillars of Spodoptera frugiperda after 6 (A), 12 (B), 24 (C) and 48 h exposure (D) to surface treated with essential oils. Fortaleza, Ceará State, Brazil.
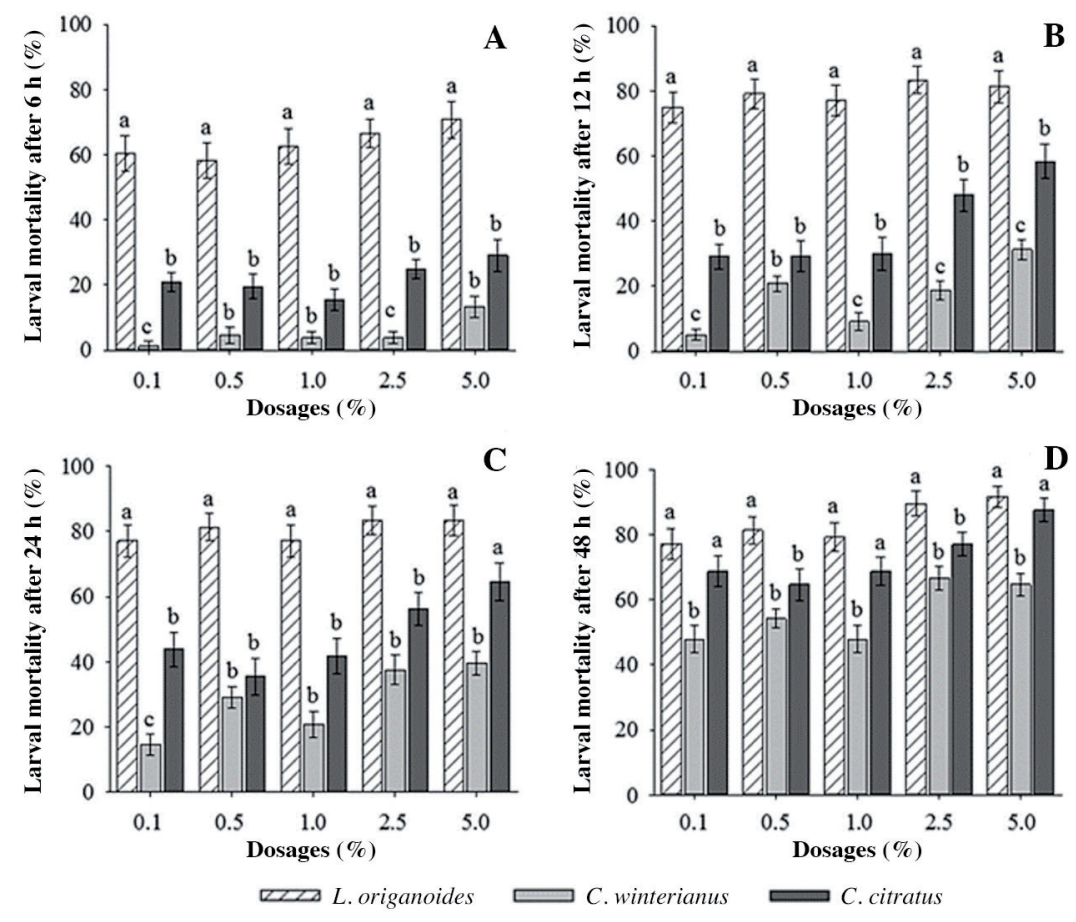

Different letters on bars corresponding to the same dosage indicate significant differences between essential oils according to Tukey test $(\mathrm{P}<0.05)$. Vertical bars correspond to standard error.

Lippia origanoides, Cymbopogon winterianus and Cymbopogon citratus.

Median lethal doses $\left(\mathrm{LD}_{50}\right)$ when analyzed through confidence intervals overlap $\left(\mathrm{CI}_{95 \%}\right)$ has been showed that the largest larvicidal potential of essential oils of $L$. origanoides and C. citratus, resulted in $\mathrm{LD}_{50}$ minor by exposure on treated surface with dilutions of only $0.001 \%$ and $0.008 \%$, respectively, to cause $50 \%$ mortality in populations of $S$. frugiperda caterpillars, and $C$. winterianus essential oil presented the greatest $\mathrm{LD}_{50}$, requiring dilutions of $0.159 \%$ to cause similar mortality rates (Table 3 ). 
Table 3. Essential oil solutions dose necessary to cause $50 \%$ larval mortality $\left(\mathrm{LD}_{50}\right)$ to $3^{\text {rd }}$ instars of Spodoptera frugiperda after 48 h exposure to treated surface. Fortaleza, Ceará State, Brazil.

\begin{tabular}{lcc}
\hline Essential oils & $\mathrm{LD}_{50}$ & $\mathrm{CI}_{95 \%}$ \\
\cline { 2 - 3 } & 0.001 & \\
Rosemary pepper (Lippia origanoides) & 0.159 & $0.0005-0.027$ \\
Citronella (Cymbopogon winterianus) & 0.008 & $0.0520-0.634$ \\
Lemongrass (Cymbopogon citratus) & & $0.0010-0.083$ \\
\hline
\end{tabular}

$\mathrm{CI}_{95 \%}: 95 \%$ confidence interval.

The exposure to essential oils also generated sublethal effects, which although fed with artificial diet, in some cases failed to reach the pupae stage or emerge as an adult, with $16 \%$ formed pupae and $12 \%$ of emerged adults from caterpillars exposed to $0.5 \%$ L. origanoides essential oil, while those exposed to $0.5 \%$ C. winterianus and C. citratus essential oils obtained $32 \%$ and $24 \%$ pupae, respectively, and equal values of emerged adults (Figure 3).

The bioassay with topical application of the essential oil solutions generated larvicidal results similar to the exposure of caterpillars to the treated surface, once again highlighting the faster action of L. origanoides essential oil, causing the highest mortality rates for $6 \mathrm{~h}$ after the treatment $97.8 \%$ of larval mortality at $5.0 \%$ and $50.0 \%$ at $0.1 \%$. The different doses of $C$. winterianus and $C$. citratus essential oils required $48 \mathrm{~h}$ to cause mortality rates close to $50 \%$, as found in the $5.0 \%$ solutions, which only reached $63.0 \%$ and $69.6 \%$ of larval mortality in the last evaluation, respectively (Figure 4). This lower larvicidal effect of $C$. winterianus and $C$. citratus essential oil solutions resulted in the highest lethal dosages $\left(\mathrm{LD}_{50}\right)$, requiring dilutions of $1.34 \%$ and $1.15 \%$ to cause $50 \%$ mortality of $S$. frugiperda caterpillars. The high contact activity of the L. origanoides essential oil resulted in lower $\mathrm{LD}_{50}$, with dilutions of $0.033 \%$ to cause $50 \%$ mortality of caterpillars, usually associated with the appearance of local necrosis and stiffening of mesothorax tissues within hours of topical application (Table 4).

The topical application of the essential oil solutions also resulted in sublethal effects on S. frugiperda caterpillars, which surviving the initial $48 \mathrm{~h}$ of evaluation and being able to feed on artificial diet, in some cases also failed to form pupae or emerge as adults, standing out for the $0.1 \%$ L. origanoides solution with only $18 \%$ pupae formed and emerged adults. While $C$. winterianus and $C$. citratus essential oil solutions induced similar effects in most dosages, causing a decrease in the number of pupae formed, or adults emerged from the pupae, showing the ability of oils to affect, reduce and even stop the lepidopteran's life cycle (Figure 5).

The spraying of $L$. origanoides, $C$. winterianus and $C$. citratus essential oils on $S$. frugiperda pupae significantly reduced the emergence of adults, displaying moderate to high pupicidal activity at five dosages of the three oils. Significant differences were found only with the lower doses, and the oils of L. origanoides and C. citratus obtained $81.3 \%$ and $78.6 \%$ at $0.1 \%$ dilution, $76.0 \%$ and $82.0 \%$ at $0.5 \%$ dilution, respectively. Significantly different from $C$. winterianus oil, which recorded only $60.0 \%$ PPA in both doses. Despite the low emergence of adults, pupal spraying did not alter pupal instar duration at most doses, except for those pupae treated with $0.1 \% \mathrm{C}$. winterianus essential oil, which had emergence of $80.0 \%$ and only $6 \mathrm{~d}$, half the time required for adult emergence after $5 \%$ neutral detergent solution application (Figure 6).

Table 4. Essential oil solutions dose necessary to cause $50 \%$ larval mortality $\left(\mathrm{LD}_{50}\right)$ to 3rd instars of Spodoptera frugiperda $48 \mathrm{~h}$ after topical application. Fortaleza, Ceará State, Brazil.

\begin{tabular}{lll}
\hline Essential oils & \multicolumn{1}{c}{$\mathrm{LD}_{50}$} & \multicolumn{1}{c}{$\mathrm{CI}_{95 \%}$} \\
\hline Rosemary pepper (Lippia origanoides) & 0.033 & $0.006-0.074$ \\
Citronella (Cymbopogon winterianus) & 1.348 & $0.429-10.356$ \\
Lemongrass (Cymbopogon citratus) & 1.151 & $0.291-5.343$ \\
\hline
\end{tabular}

$\mathrm{CI}_{95 \%}: 95 \%$ confidence. 
Figure 3. Formed pupae (A) and emerged adults (B) of Spodoptera frugiperda after $48 \mathrm{~h}$ exposure of caterpillars to surface treated with essential oils. Fortaleza, Ceará State, Brazil.

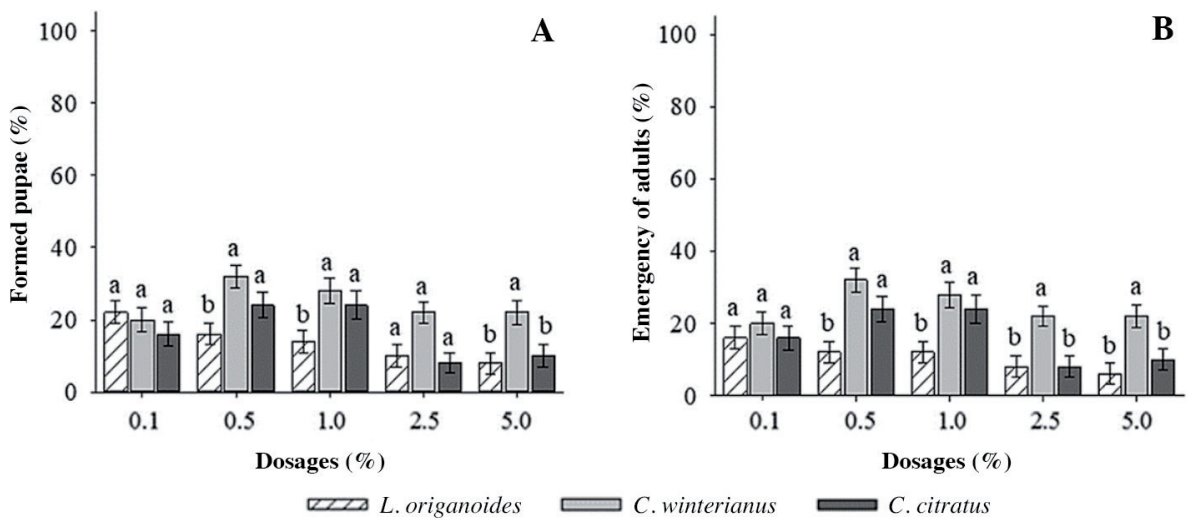

Different letters on bars corresponding to the same dosage indicate significant differences between essential oils according to Tukey test $(\mathrm{P}<0.05)$. Vertical bars correspond to standard error.

Lippia origanoides, Cymbopogon winterianus and Cymbopogon citratus.

Figure 4. Corrected mortality of Spodoptera frugiperda caterpillars 6 (A), 12 (B), 24 (C) and 48 h (D) after topical application of essential oil solutions. Fortaleza, Ceará State, Brazil.
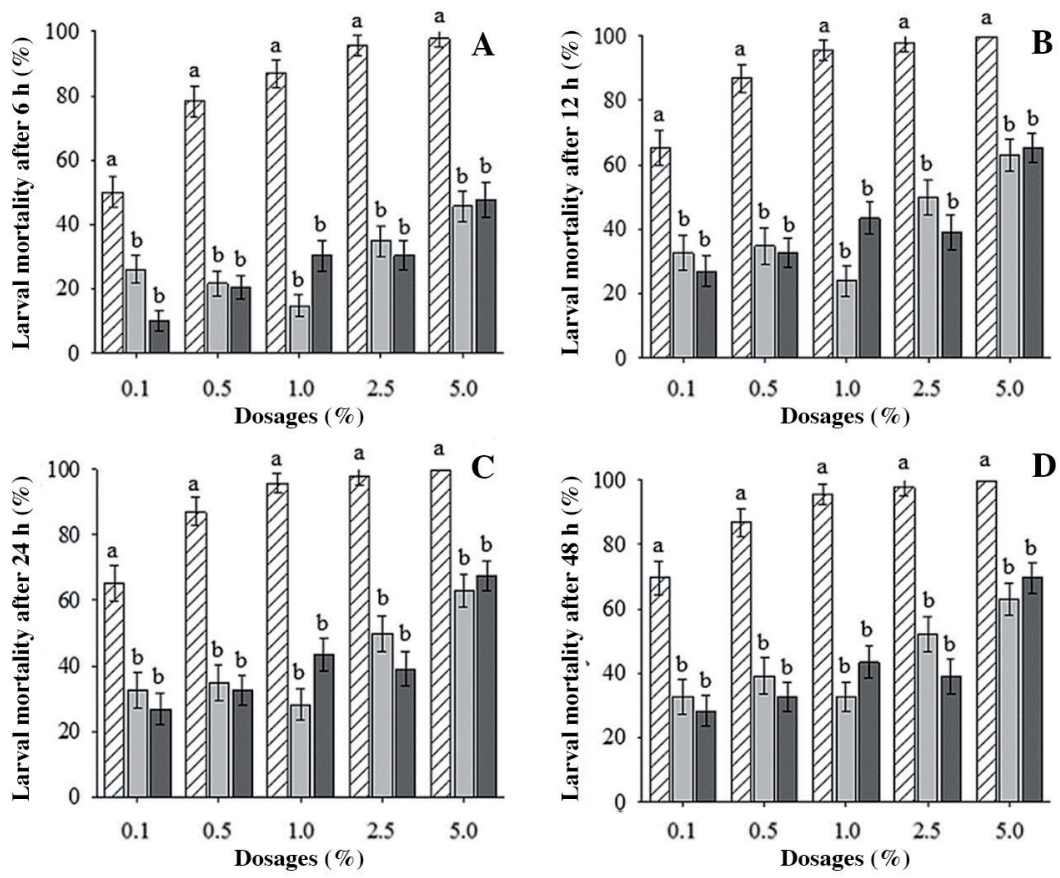

L. origanoides

C. winterianus

C. citratus

Different letters on bars corresponding to the same dosage indicate significant differences between essential oils according to Tukey test $(\mathrm{P}<0.05)$. Vertical bars correspond to standard error.

Lippia origanoides, Cymbopogon winterianus and Cymbopogon citratus. 
Figure 5. Formed pupae (A) and emerged adults (B) of Spodoptera frugiperda caterpillars that received topical application of essential oil solutions. Fortaleza, Ceará State, Brazil.
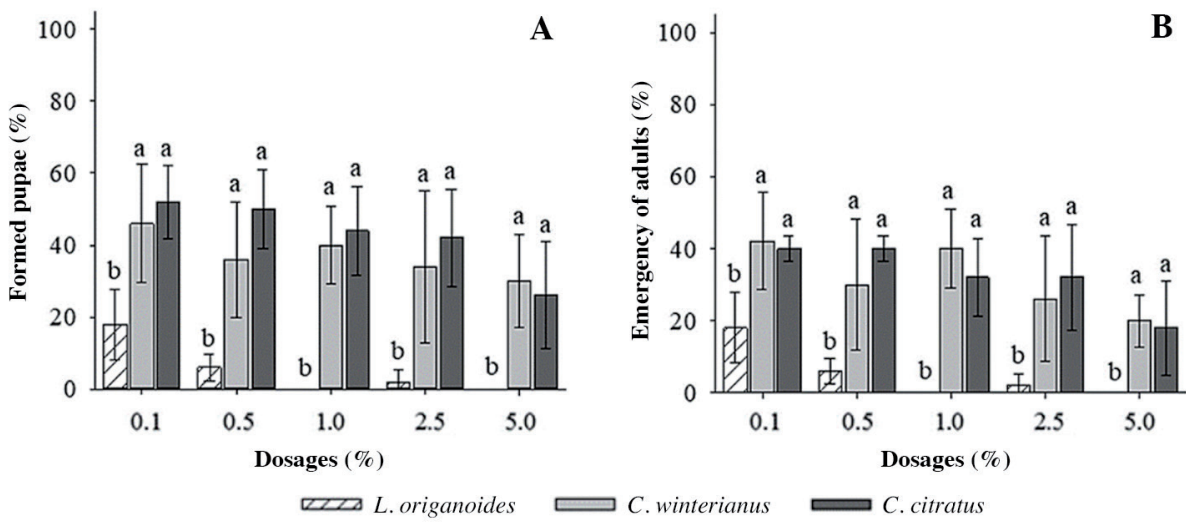

Different letters on bars corresponding to the same dosage indicate significant differences between essential oils according to Tukey test $(\mathrm{P}<0.05)$. Vertical bars correspond to standard error.

Lippia origanoides, Cymbopogon winterianus and Cymbopogon citratus.

Figure 6. Pupicidal potential (A) and duration of Spodoptera frugiperda pupal instar (B) of sprayed essential oil solutions. Fortaleza, Ceará State, Brazil.

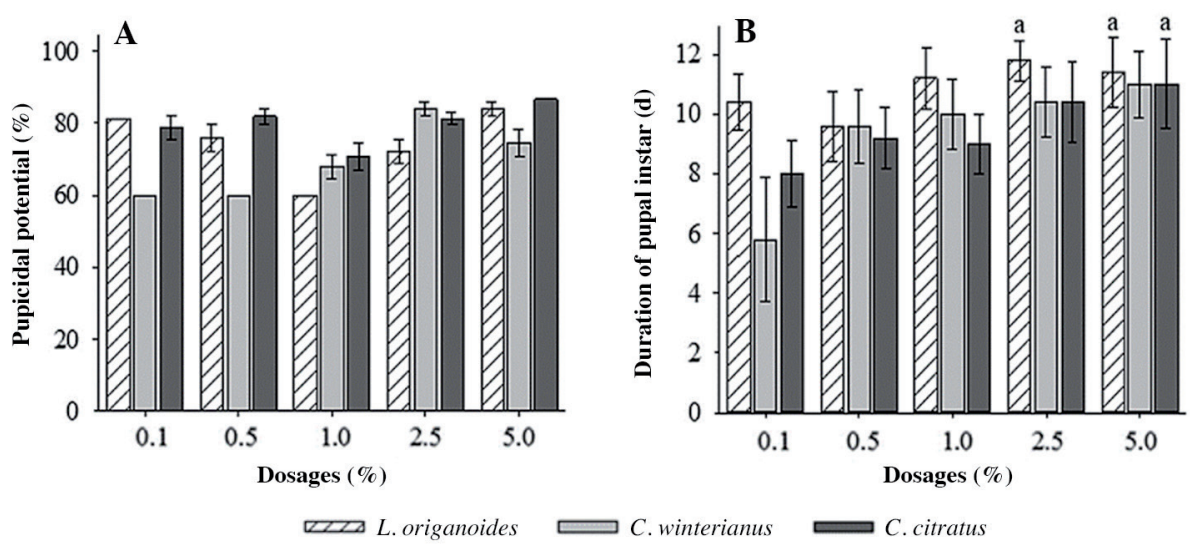

Different letters on bars corresponding to the same dosage indicate significant differences between essential oils according to Tukey test $(\mathrm{P}<0.05)$. Vertical bars correspond to standard error.

Lippia origanoides, Cymbopogon winterianus and Cymbopogon citratus.

\section{DISCUSSION}

The obtained results using essential oils of rosemary pepper (L. origanoides), citronella (C. winterianus) and lemongrass (C. citratus) against $S$. frugiperda eggs, larvae and pupae, substantiate the literature and provide additional information on the biocidal potential of extracts and essential oils (Regnault-Roger et al., 2012; Ayil-Gutiérrez et al., 2018). The main differences found are attributed mainly to the composition and mechanisms of action, which caused morphological, physiological and behavioral changes on the different instars of S. frugiperda (El-Wakeil, 2013; Campos et al., 2018).

Rosemary pepper (L.origanoides) essential oil presented the fastest action and the highest pesticidal activity against the three evaluated instars, inducing in caterpillars, hyperactivity, tremor and rigid paralysis, possibly due to energy loss and neuromuscular fatigue induced by neuroexcitation mainly attributed to the action of carvacrol (30.37\%), in addition to $\alpha$-himachalene (10.38\%), terpinolene (7.96\%), $\alpha$-pinene (5.08\%) and $\beta$-myrcene (3.90\%) (Dos Santos et al., 2016). Carvacrol has enormous insecticidal potential and is able to compete for nicotinic acetylcholine receptors (nAChRs), acting as an acetylcholinesterase (AChE) inhibitor (El-Wakeil, 2013), octopamine receptor blocker (Melo et al., 2018), or tyramine receptors (TyrR), which is a precursor of octopamine in cells of vinegar fly Drosophila melanogaster Meigen (Diptera; Drosophilidae) (Campos et al., 2018). 
The compounds present in the L. origanoides oil induced faster and potential insecticide on S. frugiperda, mainly due to the ability of the mechanisms of action to act on the central and peripheral nervous system of the insect, which allowed greater speed in neurotoxic effects when compared to the complex signaling cascades of other pathways (ElWakeil, 2013; Campos et al., 2018; Melo et al., 2018). Major compounds of L. origanoides oil and other plants of the genus Lippia, such as Lippia gracilis Schauer (Verbenaceae), also expressed ovicidal and larvicidal potential against pest arthropods of different Orders and Families, such as coleopterans like elm leaf beetle Xanthogaleruca luteola (Müller) (Coleoptera: Chrysomelidae) (Tak et al., 2015), and the red flour beetle Tribolium confusum Jacquelin du Val (Coleoptera: Tenebrionidae) (Ziaee et al., 2014); likewise some other Lepidoptera, such as cabbage looper Trichoplusia ni (Hübner) (Lepidoptera: Noctuidae) (Tak et al., 2015), Helicoverpa armigera (Hübner) (Lepidoptera: Noctuidae), spotted stemborer Chilo partellus Swinhoe (Lepidoptera Pyralidae), tobacco leafworm Spodoptera litura (F.) (Koul et al., 2013) and Egyptian cotton leafworm Spodoptera littoralis (Boisduval) (Lepidoptera: Noctuidae) (Pavela, 2011), besides the melonworm Diaphania hyalinata (L.) (Lepidoptera: Crambidae) (Melo et al., 2018) and the diamondback moth Plutella xylostella (L.) (Lepidoptera: Plutellidae), with potential to cause reductions of up to $82.2 \%$ in emergency and $48.0 \%$ larval mortality at the last one (Sangha et al., 2017).

The lower insecticidal activity of citronella (C. winterianus) essential oil, as well as the longer period to act and cause mortality, are mainly due to the mechanisms of action of $\gamma$-terpinene (18.35\%), $\beta$-caryophyllene $(3.44 \%)$ and geraniol (3.44\%), and in lower concentrations to eugenol (1.22\%) and $\beta$-myrcene (1.01\%). Geraniol can bind to the active site of acetylcholinesterase (AChE), which is responsible for the hydrolysis of acetylcholine (AChE) in cholinergic synapses, causing reversible competitive inhibition (El-Wakeil, 2013), which associated with the other compounds induced lethargy, reduction and gradual cessation of movement, progressing to paralysis, presumably due to oxygen deprivation and/or respiratory disability, due to neuroinhibition (Rattan, 2010; El-Wakeil, 2013; Campos et al., 2018).

The lemongrass $(C$. citratus) essential oil showed pesticidal activity similar to $C$. winterianus, in part due to the mechanisms of 3-carene (29.01\%), (E,E)-2,4-decadienal (25.95\%), (S)-cis-verbenol (10.42\%), isopulegol (5.75\%) and D-limonene $(0.94 \%)$, but mainly the higher concentration and the mechanism of action of $\alpha$-citral $(16.22 \%)$, which induced reversible competitive inhibition of acetylcholinesterase (AChE) similar to that observed with geraniol (Tak et al., 2015). However, despite the lower insecticidal activity observed when compared to L. origanoides oil, studies have pointed to the potential of $C$. winterianus and $C$. citratus essential oils on different pest arthropods, such as the false-worm caterpillar (T. ni), whitefly biotypes (B. tabaci) (Deletre et al., 2015), brown beetle (T. castaneum), rice weevil Sitophilus oryzae L. (Coleoptera: Curculionidae) (Olivero-Verbel et al., 2010) and corn weevil (S. zeamais) (Kabera et al., 2011).

The behavioral changes induced by citronella (C. winterianus) essential oil solutions can be attributed to the interaction between the major compound, menthone (55.97\%), a characteristic menthol aromatic monoterpene, and minority compounds such as geraniol (3.44\%), which possibly reacted with insect olfactory receptors, inducing a neurological response that resulted in antixenosis or non-preference, irritability (aggressiveness) and escape behavior (Nerio et al., 2010; Deletre et al., 2016). These changes, although not causing direct mortality, can make it difficult in practice to select hosts for food and/or oviposition, and consequently reduce crop damage.

\section{CONCLUSIONS}

The essential oils showed insecticidal activity on the egg, larvae and pupae stages of Spodoptera frugiperda, highlighting the rapid action and the high mortality rates caused by the Lippia origanoides essential oil. While essential oils of Cymbopogon citratus and C. winterianus required longer periods to act and cause significant mortality on the three stages, being that citronella oil caused behavioral changes in S. frugiperda caterpillars, which reflected flight and aggressiveness. Therefore, the use of the three essential oils can be an alternative for management of the fall armyworm, with the potential to hinder and reduce biotic potential of the lepidopteran pest. 


\section{ACKNOWLEDGEMENTS}

The authors thank the Coordenação de Aperfeiçoamento de Pessoal de Nível Superior (CAPES), Conselho Nacional de Desenvolvimento Cientifico e Tecnológico (CNPq) and Fundação Cearense de Apoio ao Desenvolvimento Científico e Tecnológico (FUNCAP) for granting scholarships and financial support; to the laboratories of the UFC and AGROPAULO Agroindustrial S/A.

\section{REFERENCES}

Abbott, W.S. 1925. A method of computing the effectiveness of an insecticide. Journal of Economic Entomology 18:265-267. doi:10.1093/jee/18.2.265a.

Adams, R.P. 2007. Identification of essential oil components by gas chromatography/mass spectrometry. $4^{\text {th }}$ ed. Allured Publishing Corporation, Carol Stream, Illinois, USA.

Alves, S.D., Carvalho, G.A., Oliveira, D.F., and Corrêa, A.D. 2018. Screening of Brazilian plant extracts as candidates for the control of Spodoptera frugiperda (Lepidoptera: Noctuidae). Revista Colombiana de Entomología 44:32-38. doi:10.25100/ socolen.v44i1.6539.

Ayil-Gutiérrez, B.A., Sánchez-Teyer, L.F., Vazquez-Flota, F., Monforte-González, M., Tamayo-Ordóñez, Y., TamayoOrdóñez, M.C., et al. 2018. Biological effects of natural products against Spodoptera spp. Crop Protection 114:195-207. doi:10.1016/j.cropro.2018.08.032.

Baskar, K., Kingsley, S., Vendan, S.E., Paulraj, M.G., Duraipandiyan, V., and Ignacimuthu, S. 2009. Antifeedant, larvicidal and pupicidal activities of Atalantia monophylla (L) Correa against Helicoverpa armigera Hubner (Lepidoptera: Noctuidae). Chemosphere 75:355-359. doi:10.1016/j.chemosphere.2008.12.034.

Bateman, M.L., Day, R.K., Luke, B., Edgington, S., Kuhlmann, U., and Cock, M.J. 2018. Assessment of potential biopesticide options for managing fall armyworm (Spodoptera frugiperda) in Africa. Journal of Applied Entomology 142:805-819. doi:10.1111/jen.12565.

Benelli, G., Canale, A., Toniolo, C., Higuchi, A., Murugan, K., Pavela, R., et al. 2017. Neem (Azadirachta indica): towards the ideal insecticide? Natural Product Research 31:369-386. doi:10.1080/14786419.2016.1214834.

Botha, A.S., Erasmus, A., du Plessis, H., and Van den Berg, J. 2019. Efficacy of Bt maize for control of Spodoptera frugiperda (Lepidoptera: Noctuidae) in South Africa. Journal of Economic Entomology 112:1260-1266. doi:10.1093/jee/toz048.

Campos, E.V., Proença, P.L., Oliveira, J.L., Bakshi, M., Abhilash, P.C., and Fraceto, L.F. 2018. Use of botanical insecticides for sustainable agriculture: Future perspectives. Ecological Indicators 105:1-13. doi:10.1016/j.ecolind.2018.04.038.

Deletre, E., Chandre, F., Barkman, B., Menut, C., and Martin, T. 2016. Naturally occurring bioactive compounds from four repellent essential oils against Bemisia tabaci whiteflies. Pest Management Science 72:179-189. doi:10.1002/ps.3987.

Deletre, E., Mallent, M., Menut, C., Chandre, F., and Martin, T. 2015. Behavioral response of Bemisia tabaci (Hemiptera: Aleyrodidae) to 20 plant extracts. Journal of Economic Entomology 108:1890-1901. doi:10.1093/jee/tov118.

Dos Santos, A.C.V., Fernandes, C.C., Lopes, L., and Sousa, A.H.D. 2016. Insecticidal oils from Amazon plants in control of fall armyworm. Revista Caatinga 29:642-647. doi:10.1590/1983-21252016v29n314rc.

Early, R., González-Moreno, P., Murphy, S.T., and Day, R. 2018. Forecasting the global extent of invasion of the cereal pest Spodoptera frugiperda, the fall armyworm. NeoBiota 40:25-50. doi:10.3897/neobiota.40.28165.

El-Wakeil, N.E. 2013. Botanical pesticides and their mode of action. Gesunde Pflanzen 65:125-149. doi:10.1007/s10343-013-0308-3.

Finney, D.J. 2009. Probit analysis. $4^{\text {th }}$ ed. Cambridge University Press, London, UK.

Goergen, G., Kumar, P.L., Sankung, S.B., Togola, A., and Tamò, M. 2016. First report of outbreaks of the fall armyworm Spodoptera frugiperda (J.E. Smith) (Lepidoptera, Noctuidae), a new alien invasive pest in West and Central Africa. PLOS ONE 11:e0165632. doi:10.1371/journal.pone.0165632.74.

González-Castillo, J.A., Quezada-D’Angelo, T.P., Silva-Aguayo, G.I., and Moya-Elizondo, E.A. 2018. Effect of saponins of Quillaja saponaria extracts in combination with Pseudomonas protegens to control Gaeumannomyces graminis var. tritici in wheat. Chilean Journal of Agricultural Research 78:378-390. doi:10.4067/S0718-58392018000300378.

Greene, G.L., Leppla, N.C., and Dickerson, W.A. 1976. Velvetbean caterpillar: A rearing procedure and artificial medium. Journal of Economic Entomology 69:487-488. doi:10.1093/jee/69.4.487.

Isman, M.B. 2015. A renaissance for botanical insecticides? Pest Management Science 71:1587-1590. doi:10.1002/ps.4088.

Kabera, J., Gasogo, A., Uwamariya, A., Ugirinshuti, V., and Nyetera, P. 2011. Insecticidal effects of essential oils of Pelargonium graveolens and Cymbopogon citratus on Sitophilus zeamais (Motsch.) African Journal of Food Science 5:366-375.

Koul, O., Singh, R., Kaur, B., and Kanda, D. 2013. Comparative study on the behavioral response and acute toxicity of some essential oil compounds and their binary mixtures to larvae of Helicoverpa armigera, Spodoptera litura and Chilo partellus. Industrial Crops and Products 49:428-436. doi:10.1016/j.indcrop.2013.05.032. 
Melo, C.R., Picanco, M.C., Santos, A.A., Santos, I.B., Pimentel, M.F., Santos, A.C., et al. 2018. Toxicity of essential oils of Lippia gracilis chemotypes and their major compounds on Diaphania hyalinata and non-target species. Crop Protection 104:47-51. doi:10.1016/j.cropro.2017.10.013.

Mendoza-García, E.E., Ortega-Arenas, L.D., Serrato-Cruz, M.Á., Villanueva-Jiménez, J.A., López-Arroyo, J.I., and PérezPacheco, R. 2019. Chemical composition, toxicity, and repellence of plant essential oils against Diaphorina citri (Hemiptera: Liviidae). Chilean Journal of Agricultural Research 79:636-647. doi:10.4067/S0718-58392019000400636.

Nerio, L.S., Olivero-Verbel, J., and Stashenko, E. 2010. Repellent activity of essential oils: a review. Bioresource Technology 101:372-378. doi:10.1016/j.biortech.2009.07.048.

Oliveira, A.R.M.F., Oliveira, L.M., Carneiro, J.S., Silva, T.R.S., and Costa, L.C.B. 2018. Essential oil of Lippia sidoides and its major compound thymol: Toxicity and walking response of populations of Sitophilus zeamais (Coleoptera: Curculionidae). Crop Protection 112:33-38. doi:10.1016/j.cropro.2018.05.011.

Olivero-Verbel, J., Nerio, L.S., and Stashenko, E.E. 2010. Bioactivity against Tribolium castaneum Herbst (Coleoptera: Tenebrionidae) of Cymbopogon citratus and Eucalyptus citriodora essential oils grown in Colombia. Pest Management Science 66:664-668. doi:10.1002/ps.1927.

Pavela,R. 2011. Antifeedant and larvicidal effects of some phenolic components of essential oils lasp lines of introduction against Spodoptera littoralis (Boisd.) Journal of Essential Oil Bearing Plants 14:266-273. doi:10.1080/0972060X.2011.10643932.

Pinheiro, P.F., Queiroz, V.T.D., Rondelli, V.M., Costa, A.V., Marcelino, T.D.P., and Pratissoli, D. 2013. Insecticidal activity of citronella grass essential oil on Frankliniella schultzei and Myzus persicae. Ciência e Agrotecnologia 37:138-144. doi:10.1590/S1413-70542013000200004.

Rattan, R.S. 2010. Mechanism of action of insecticidal secondary metabolites of plant origin. Crop Protection 29:913-920. doi:10.1016/j.cropro.2010.05.008.

Regnault-Roger, C., Vincent, C., and Arnason, J.T. 2012. Essential oil in insect control: Low risk products in a high-state world. Annual Review Entomology 57:405-424. doi:10.1146/annurev-ento-120710-100554.

Sangha, J.S., Astatkie, T., and Cutler, G.C. 2017. Ovicidal, larvicidal, and behavioural effects of some plant essential oils on diamondback moth (Lepidoptera: Plutellidae). The Canadian Entomologist 149:639-648. doi:10.4039/tce.2017.13.

Suwansirisilp, K., Visetson, S., Prabaripai, A., Tanasinchayakul, S., Grieco, J.P., Bangs, M.J., et al. 2013. Behavioral responses of Aedes aegypti and Culex quinquefasciatus (Diptera: Culicidae) to four essential oils in Thailand. Journal of Pest Science 86:309-320. doi:10.1007/s10340-012-0464-8.

Tak, J.H., Jovel, E., and Isman, M.B. 2015. Contact, fumigant, and cytotoxic activities of thyme and lemongrass essential oils against larvae and an ovarian cell line of the cabbage looper, Trichoplusia ni. Journal of Pest Science 89:183-193. doi:10.1007/s10340-015-0655-1.

Vite-Vallejo, O., Barajas-Fernández, M.G., Saavedra-Aguilar, M., and Cardoso-Taketa, A. 2018. Insecticidal effects of ethanolic extracts of Chenopodium ambrosioides, Piper nigrum, Thymus vulgaris, and Origanum vulgare against Bemisia tabaci. Southwestern Entomologist 43:383-394. doi:10.3958/059.043.0209.

Ziaee, M., Moharramipour, S., and Mohsenifar, A. 2014. Toxicity of Carum copticum essential oil-loaded nanogel against Sitophilus granarius and Tribolium confusum. Journal of Applied Entomology 138:763-771. doi:10.1111/jen.12133. 